\title{
ANALYSIS OF OPTIMAL COSTS FOR RESERVES OF SPARE PARTS FOR AGRICULTURAL MACHINES
}

\section{Marjan Mirčevski ${ }^{1}$, Milan Mihajlović2 ${ }^{2}$ Milan Milunović3 ${ }^{3}$ Ivan Milojević ${ }^{4}$, Radovan

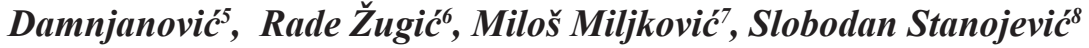

\section{Summary}

Managing reserves of spare parts for agricultural machinery in agricultural farms represents one of the most important activities in securing smooth functioning, especially having in mind the imperative of continuous agricultural production. Aims of this study were to show how efficiency of the agricultural farms as a business subject can be secured by determining timely purchase of spare parts by using a stochastic model of supplies on one side and reduce the time of malfunction of agricultural machinery on the other. Study of optimal inventory level was conducted in agricultural holdings on the territory Banat in 2015 based on data on spare parts purchase and malfunction of agricultural machinery. Acquired data was related to frequency of defects and the need for spare parts, as well as the price of spare parts, where the data was processed with the use of stochastic model of supplies. The optimal number of spare parts for the observed equipment in the observed period was $y^{*}=4$ with the probability of $85 \%$ that this amount of spare parts will be sufficient for all malfunctions on the equipment to be eliminated, while taking a 15\% risk that one or two spare parts

1 Marjan Mirčevski, Ph.D., Assistant Professor, Military Medical Academy, Belgrade, Crnotravska 17, 11000 Belgrade, Serbia, E-mail: marjan.mircevski@gmail.com

2 Milan Mihajlović, PhD, Assistant Professor, Military Academy, University of Defence, Pavla Jurišića Šturma br. 33, 11000 Belgrade, Serbia, e-mail: milan.mih83@gmail.com.

3 Milan Milunović, PhD., Assistant Professor, Budget Department, Ministry of Defense, Birčaninova 5, 11000 Belgrade, Serbia.

4 Ivan Milojević, PhD., General Staff of the Serbian Armed Forces, Belgrade, Gardijska 7, 11000 Belgrade, Serbia.

5 Radovan Damnjanović, PhD. Assistant Professor, General Staff of the Serbian Armed Forces, Belgrade, Gardijska 7, 11000 Belgrade, Serbia, E-mail: radovandam78@gmail.com

6 Rade Žugić, PhD., Asocciate Professor, School of Economisc and Management Studies, Karađorđeva 52, 34000 Kragijevac.

7 Miloš Miljković, student MA, Military Academy, University of Defence, Pavla Jurišića Šturma br. 33, 11000 Belgrade, Serbia

8 Slobodan Stanojević, PhD, Assistant Professor, Modern Bussines School, Belgrade, Terazije 27. 
will be acquired with emergency procurements in case of extraordinary circumstances. The model of managing supplies represented in such a way provides an opportunity to be easily applied in agricultural farms, where the values of an optimal solution would be effectively got with previously chosen values of suitable parameters, thus minimizing total expected costs, which would include fixed costs, expenses caused by unsatisfied requests, where the time of waiting for the observed equipment to be fixed would be taken into account.

Key words: Stochastic model of supplies, spare parts, agricultural machinery, farm.

\section{Introduction}

In the last 50 years, the importance of agriculture in macroeconomic conditions has been reduced. In favour of this is the fact that in the middle of the 20th century, 50\% of the EU population worked in agriculture, and primary agricultural production was a traditional source of income in rural areas. In the meantime, this share is continuously decreasing, so today only $7 \%$ of the EU population is engaged in agriculture. This is the result of major technical and structural changes in the global market resulting in the globalization of agricultural production and strong competition in the primary agricultural sector (Milić, 2011)

Such processes are strongly present especially in the countries in transition, where they have resulted in very negative trends and today's unfavorable situation characterized by numerous problems: small and non-competitive production, a large number of old farms, fragmented agricultural land, small production plots, extensive and low technological basis of production, insufficient use of agro-technical measures, poor productivity, etc. Such agriculture is poorly income, non-competitive and unprofitable, and in the current state it can not be a condition of a sustainable military.

This state of affairs is unsustainable, since in small environments it causes more severe living and working conditions, the deterioration of existing agricultural holdings, unemployment, and major structural disorders: depopulation, loss of agricultural land function, social decline, loss of identity of local communities, and exposure to harmful phenomena such as endangering the environment, etc.

Quality realization of agricultural production also depends on contemporary of the households with modern means and equipment. It is very important for this equipment not to be faulty in order to insure continuity in work and to ensure that the needs of ever increasing production are met (Harrington, 2007). In accordance with that is reducing time of defectiveness of these devices, which is achieved by the possibility of faster repairs and returning it in functioning state. The successful realization of this request (Vukoje, 2013) is achieved by the existence of adequate inventory of spare parts, which is realized through the system of supplying material resources which, in principle represents the set of diverse elements of connected information and material flow in a unified whole. 
The supply system can perform its function only with the existence of certain inventory and spare material assets. They are a component of the system and represent one of the sources of supplying (Riveiro, 2010)

Stocks of spare parts, located at appropriate locations, can prevent long downtimes of technical systems that are used in primary processes of their users (Milojević, Mihajlović, Cvijanović, 2012). Since such downtimes are typically very expensive, generally system-oriented service measures are used in spare parts reserve control. Examples of such measures are system availability and the expected number of backorders over all spare parts (Karugia, 2017; Kranenburg, 2006).

Managing supplies is surely one of the most important logistic assignments of every agricultural farm. Problems that make finding the optimal policy of managing supplies difficult are: the unpredictability of demand, long time period of delivery, unreliability of suppliers, large number of articles, short time period of demand for certain products.

Obviously, having adequate numbers of spare parts is of key importance for this repairby-replacement policy to be effective. However, spare parts stocks may tie up a lot of capital: commercial airlines are estimated to have over $\$ 40$ billion worth of spare parts, a single company such as ASML, which builds lithography equipment used in semiconductor manufacturing, owns spare parts worth tens of millions of euros, and the US Coast Guard Aircraft owns inventories worth over \$700 million (Smith, Pitt, 2007).

Managing supplies is often a neglected activity in a large number of systems even though it is of crucial importance for realizing assigned missions and tasks. Having in mind that managing supplies is too complex of a problem for thorough, detailed analysis, by using superficial analysis we can come to the conclusion that it is best to have as much supplies as finances allow(Walczak, Caban, Marczuk, 2017; Guillermo, 2017). However, even though keeping high level of supplies is sometimes followed by great expenses, comparing those costs with costs that occur due to emergency procurements, it can be seen that it is significantly more responsible to have an appropriate level of supplies. It is especially in this case, having in mind the significance ${ }^{9}$ of agricultural machinery for undisturbed production.

\section{Methods}

Researching supplies of spare parts undisturbed production was performed on in rural farms in Banat. The research was conducted due to the need to improve the work of farm and to rationalize the spending of approved budget assets (Basten, Houtum, 2014) which imposes the request to analyse the expenses of maintaining agricultural machinery s in farms, because data from previous years show a growth in these costs (Božić, Aćimović, 2010). This situation is conditioned by non-existence of adequate supplies of spare parts, which often leads to a standstill in work of certain wholes of farms. Creation of the right model of managing supplies of spare parts for agricultural machinery needs to answer two basic questions: how and in what amount should these parts be ordered from the supplier (Brown, 2008). Research that was conducted showed 
us that the answer to these questions depends on: a) total cost of holding supplies, b) cost of storing supplies and c) cost of handling supplies.

When managing replenishment of supplies, two general approaches are used (Backović, Vuleta, Popović, 2014):

1. Continuous replenishment system, which implies that the level of supplies is tracked continuously and its replenishment is done when it falls under the specified level, with fixed amounts of newly delivered goods. In this case the amounts that are delivered are fixed, and the variable is the period between two procurements. This is why this system is known as the system of fixed orders.

2. Periodical replenishment system which implies that orders are done in fixed intervals, irrelevant of the available stocks, where the ordered amount is determined in the amount to secure a predefined volume of supplies. In this case the interval between orders is fixed and the amount ordered is the variable. This is why this system is called the system of fixed intervals. The level of supplies in this system is determined by taking a periodical inventory in objects in which supplies are present.

During purchase of such supplies such as, parts for an ultrasound apparatus etc., there can be a dilemma: is it cost-effective to secure spare parts for maintenance of a device with its purchase or is it cost-effective for those spare parts to be ordered when a malfunction occurs. In the first case there will be storage costs, while in the other case there will be a problem in the form of inability for the farms to provide services to a patient in a particular time period, and costs of emergency procurement which is done so that malfunction is dealt with as soon as possible.

The fact that all costs, i.e. total costs are tied to securing reserves of spare parts should be as small as possible. In order for the set problem to be solved, it is necessary to formulate the corresponding mathematical problem of supplies(Caffaro, Mirisola, Cavallo, 2017) and then determine the minimal total cost of supplies by solving it. To form such mathematical model of supplies it is necessary for the following conditions and assumptions to be solved: (Backović, Vuleta, Popović, 2014).

- In the given time period $T$, the demand for spare parts, i.e. frequency of failure occurrences agricultural machinery, marked with $x$, which is a stochastic variable with the known law of probability $p(x)$;

- Cost of supplies of spare parts per unit, if they are acquired through regular channels are $C_{1}$;

- Cost of supplies per unit, if they are acquired in urgent situations are $C_{2}$. These costs can include costs of agricultural machinery holdup due to lack of supplies. It is common in practice for costs $C_{2}$ to be significantly greater than costs $C_{1}$;

- Initial supplies are equal to zero;

- If $x$ marks demand and $y$ supply, then: if $x \leq y$, i.e. when the level of supplies greater 
than demand, cost of supplies that will be paid is $C_{1}(y-x)$; if $y>x$, i.e. when demand is greater than available supply, cost of emergency procurement that will be paid is $C_{1}(y-x)$.

Having in mind that demand $x$ is stochastic and that the probability of malfunction on a agricultural machinery(Gauchan, Shrestha, 2017) is known $p(x)$ which means that that expected total costs will be obtained by adding individual expenses for each $x$, multiplied by corresponding probability $p(x)$, so that the function of total expenses, marked with $F(y)$, reduced to an expected value can be written in the following form:

$$
F(y)=C_{1} \sum_{x=0}^{y}(y-x) p(x)+C_{2} \sum_{x=y+1}^{\infty}(x-y) p(x)
$$

In order to determine minimal expected total expenses for the presented problem of supplies, it is necessary to determine the minimum of this function. Having in mind that this model relates to securing supplies of spare parts for agricultural machinery, minimization of this function(Gościański, Kośmicki, Mielec,2005) will be conducted under the assumption that the variables can be taken only as individual and whole numbered, nonnegative values. In that case, if there is a value $y^{*}$ where the previously specified function takes its minimal value then the following condition must be met

$$
F\left(y^{*}-1\right)>F\left(y^{*}\right)<F\left(y^{*}+1\right)
$$

If functions $F(y-1)$ and $F(y+1)$ are formed then condition under which $y=y^{*}$ should be determined.

Starting from function (1) in which the variable $y$ is replaced with $y$-1 then we get

$$
F(y-1)=C_{1} \sum_{x=0}^{y-1}(y-1-x) p(x)+C_{2} \sum_{x=y}^{\infty}(x-y+1) p(x)
$$

respectively

$$
F(y-1)=C_{1} \sum_{x=0}^{y-1}(y-x) p(x)+C_{2} \sum_{x=y}^{\infty}(x-y) p(x)-C_{1} \sum_{x=0}^{y-1} p(x)+C_{2} \sum_{x=y}^{\infty} p(x)
$$

Based on the connection between functions $F(y)$ and $F(y-1)$, the connection between functions $F(y)$ and $F(y+1)$ can be established, which can be written in the form of the following double inequality ${ }^{16}$

$$
p\left(x \leq y^{*}-1\right)<\frac{C_{2}}{C_{1}+C_{2}}<p\left(x \leq y^{*}\right)
$$

This means that if there is a value $y^{*}$ that minimizes the function of expected total expenses, then $y^{*}$ must fulfil the conditions given by the relation (5). Relation (5) is important, not only because conditions of optimality that the variable $y$ must fulfil are determined by it, but because it can be used to determine the optimal value of supplies $y^{*}$ that minimizes expected expenses of supplies. 
This is achieved by firstly forming a table in which one row or column represents the cumulative of probabilities $p(x=y)$, and then based on known values for $C_{1}$ and $C_{2}$ the quotient is calculated:

$$
k=\frac{C_{2}}{C_{1}+C_{2}}
$$

After this, cumulative probabilities between which the quotient $k$ can be found are determined based on cumulative probability in the row or column. There is one value $y$ that corresponds to each of these cumulative probabilities $p(x=y)$. Value that corresponds to the greater value of cumulative probabilities for $y$, represents the sought optimal solution $y^{*}$.

By using the relation (5), analysis of the optimal solution can be performed, i.e. limits can be determined, within which expenses $C_{1}$ и $C_{2}$ can be found, without causing a change to the optimal solution.

$$
\begin{gathered}
C_{1}<\frac{p\left(x \geq y^{*}\right)}{p\left(x \leq y^{*}-1\right)} \\
C_{1}>\frac{p\left(x \geq y^{*}+1\right)}{p\left(x \leq y^{*}\right)} \cdot C_{2}
\end{gathered}
$$

because

$$
p\left(x \leq y^{*}\right)=1-p\left(x>y^{*}\right)=1-p\left(x \geq y^{*}+1\right)
$$

Inequalities (7) and (8) can be unified in one dual inequality

$$
\frac{p\left(x \geq y^{*}+1\right)}{p\left(x \leq y^{*}\right)} \cdot C_{2}<C_{1}<\frac{p\left(x \geq y^{*}\right)}{p\left(x \leq y^{*}-1\right)} \cdot C_{2}
$$

where the lower and upper limit are determined within which expenses $C_{1}$ can be found, without causing a change in the optimal solution.

The lower and upper border within which expenses $C_{2}$ can change, without causing a change in the optimal solution are

$$
\frac{p\left(x \leq y^{*}+1\right)}{1-p\left(x \leq y^{*}-1\right)} \cdot C_{1}<C_{2}<\frac{p\left(x \leq y^{*}\right)}{1-p\left(x \leq y^{*}\right)} \cdot C_{1}
$$

Or written differently

$$
\frac{p\left(x \leq y^{*}+1\right)}{p\left(x \geq y^{*}\right)} \cdot C_{1}<C_{2}<\frac{p\left(x \leq y^{*}\right)}{p\left(x \geq y^{*}+1\right)} \cdot C_{1}
$$

\section{Results}

Research was conducted by reviewing 125 agricultural machinery where the average cost of acquisition and storing spare parts during purchase of agricultural machinery, per part was $C_{l}=1.500 €$. In the case when spare parts weren't acquired at the time 
of purchase of agricultural machinery but when a malfunction occurred, the period of putting the device out of use was averagely two months and the expenses for emergency procurement were in average $C_{l}=1.500 €$. By reviewing the data during the research period, the probabilities of replacing spare parts in the exploitation period of the agricultural machinery were calculated. These probabilities can be expressed in a table in the following way:

Table 1. Probability of replacing spare parts

\begin{tabular}{|l|l|l|l|l|l|l|l|l|}
\hline $\begin{array}{l}\text { Number of replaced spare } \\
\text { parts } \boldsymbol{x}\end{array}$ & 0 & 1 & 2 & 3 & 4 & 5 & 6 & 7 \\
\hline $\begin{array}{l}\text { Probability of replacement } \\
\boldsymbol{p}(\boldsymbol{x})\end{array}$ & 0 & 0,25 & 0,30 & 0,20 & 0,10 & 0,10 & 0,05 & 0 \\
\hline
\end{tabular}

Source: authors' calculations;

During the application of the mentioned model, the problem of determining the optimal size of order of spare parts $y^{*}$ was set, in a regular way, for which total expenses of securing supplies will be minimal, then determining the amount of those minimal expenses and the limit within which expenses $C_{1}$ и $C_{2}$ can change, while leaving the optimal solution unchanged (Cruz, Rincon, 2012).

Starting from initial sizes $C_{1}=1.500 €$ and $C_{2}=6.000 €$, the following can be determined

$$
k=\frac{6.000}{1.500+6.000}=0,8
$$

After this it is necessary to make the table in which the row of cumulative probabilities $p(x \leq y)$ will exist.

Table 2. Probabilities and cumulative probabilities of changing spare parts

\begin{tabular}{|l|l|l|l|l|l|l|l|l|}
\hline $\boldsymbol{y}$ & 0 & 1 & 2 & 3 & 4 & 5 & 6 & 7 \\
\hline $\boldsymbol{x}$ & 0 & 1 & 2 & 3 & 4 & 5 & 6 & 7 \\
\hline $\boldsymbol{p}(\boldsymbol{x})$ & 0 & 0,25 & 0,30 & 0,20 & 0,10 & 0,10 & 0,05 & 0 \\
\hline $\boldsymbol{p}(\boldsymbol{x} \leq \boldsymbol{y})$ & 0 & 0,25 & 0,55 & 0,75 & 0,85 & 0,95 & 1,00 & 1,00 \\
\hline
\end{tabular}

Source: authors' calculations;

Based on the data from the table we received

$$
0,75<k<0,85
$$

for cumulative probabilities $p(x \leq y)$ which means that

$$
y^{*}=4
$$

because this value corresponds to greater cumulative probability for $y$.

This result indicates that with regular procurement $y^{*}=4$ spare parts should have been supplied, where it can be determined with the probability of $85 \%$ that this amount of 
spare parts will be sufficient to eliminate all malfunctions on the observed agricultural machinery while taking the risk of $15 \%$ that one or two spare parts will have to be acquired by regular procurement in the case of nonexistence of supplies. In that case minimal expenses would be

$$
F\left(y^{*}=4\right)=1.500 \sum_{x=0}^{4}(4-x) p(x)+6.000 \sum_{x=5}^{\propto}(4-x) p(x)
$$

respectively

$$
F\left(y^{*}=4\right)=1.500(3 \cdot 0,25+2 \cdot 0,30+1 \cdot 0,20)+6.000(1 \cdot 0,10+2 \cdot 0,05)=3.525 €
$$

In order to be assured that these are indeed minimal expenses, a crosscheck was performed and expenses $F\left(y^{*}-1=3\right)$ and $F\left(y^{*}+1=5\right)$ were calculated,

$$
F(3)=1.500(2 \cdot 0,25+1 \cdot 0,30)+6.000(1 \cdot 0,10+2 \cdot 0,10+3 \cdot 0,05)=3.900 €
$$

and

since

$$
F(5)=1.500(4 \cdot 0,25+3 \cdot 0,30+2 \cdot 0,20+1 \cdot 0,10)+6.000(1 \cdot 0,05)=3.900 €
$$

$$
F(3)>F(4)<F(5)
$$

These are indeed minimal expenses for $y^{*}=4$, so the only thing left is to determine the limits of change for expenses $C_{1}$ and $C_{2}$, for which there will not be a change in the optimal solution. These limits can be determined by relations (8) and (12), which means that for the borders of change for expenses $C_{1}$ it can be written

respectively

$$
\frac{p(x \geq 5)}{p(x \leq 4)} \cdot 6.000<C_{1}<\frac{p(x \geq 4)}{p(x \leq 3)} \cdot 6.000
$$

$$
\frac{0,15}{0,85} \cdot 6.000<C_{1}<\frac{0,25}{0,75} \cdot 6.000
$$

where the asked limits for the change in expenses $C_{1}$ are finally determined

$$
1.058,82<C_{1}<2.000,00
$$

Just as in the previous case, the limits within which expenses $C_{2}$ can be found without changing the optimal solution $y^{*}=4$ will be

where we get

$$
\frac{0,75}{0,25} \cdot 1.500<C_{2}<\frac{0,85}{0,15} \cdot 1.500
$$

$$
4.500,00<C_{2}<8.500,00
$$

In order to perform the crosscheck, it can be assumed firstly that $C_{1}=1200$, and then that $C_{1}=1.890$. 
In the first case

$$
k=\frac{6.000}{1200+6.000}=0,8333
$$

and in the second

$$
k=\frac{6.000}{1.890+6.000}=0,7604
$$

thus in both cases it is

$$
0,75<k<0,85
$$

Which means that the mentioned changes in expenses $C_{1}$ didn't influence the change in the optimal solution $y^{*}=4$.

A similar crosscheck can be performed for expenses $C_{2}$, which means that the changes in expense $C_{2}$ will not lead to a change in the optimal solution $y^{*}=4$.

\section{Discussion}

There are not many references comparing or discussing questions tied to supply of spare parts for agricultural machinery, especially applying a mathematical model in reviewing economic management of the same. Many authors point to the significance of agricultural machinery, especially its functioning. However there are only a few who model expenses that occur due to maintenance of agricultural machinery and equipment.

Considering that there isn't an ideal level of functional agricultural machinery and with it spare parts, it is necessary to conduct a large number of studies in order to help managers of farm when projecting the amount of financial assets intended to the mentioned use (Deshpande, Iyer, Cho, 2006). Considering the specificity of every farm, with an emphasis on the quality of agricultural machinery, there is a possibility for eventual savings in their maintenance.

Managing is a strategic function and makes a positive contribution to business growth and organization success. This is a diverse profession whose main aim is to provide quality environment, which is fit for the purpose it's designed for. It also involves a constant balancing act between the competing pressures of time, cost and quality (Zekić, Šegrt, 2015)

Savings that would be achieved with the purchase of spare parts during the acquisition of agricultural machinery in relation to expenses that occur in the case of nonexistence of supplies of spare parts in the observed sample of 125 agricultural machinery are great. Also unrealized revenue due to defects additionally increases loss.

In our research it was shown that funds can be saved if optimal amount of spare parts would be acquired $\mathrm{y}^{*}=4$ over $12,000 €$ with the probability of malfunction on the observed agricultural machinery of $85 \%$. In this case there is a risk with the probability of $15 \%$ for a malfunction to occur without having a previously acquired spare part in 
favourable conditions. On the other hand, existence of supplies would expedite repair of agricultural machinery in the shortest possible period which would reduce the time in which the observed device has a defect and additionally influence an increase in trust of patients in farms and of course increase revenue.

This type of systematic approach to determining the level of supplies has shown significant results in other areas as well. Rustenburg et al.21 show that for one system, spare parts holding costs would reduce by about $60 \%$ under the system approach, while attaining a slightly higher spare parts availability; for another system, the spare parts holding costs would reduce by $9 \%$, while bringing the availability up from $56 \%$ to $90 \%$ (Rustenburg et al., 2013).

\section{Conclusion}

Based on the aforementioned it can be concluded that preventive maintenance agricultural machinery which is manifested in the form of timely procurement of spare parts, a significant form of achieving efficient and cost-effective operating of farms.

Results of our study indicate that mathematical modelling of expenses of supplies of spare parts for agricultural machinery can contribute to successful reviewing of the best way of acquiring the same. Therefore it is necessary for the management of farms to take appropriate steps to achieve planned savings and an increase in quality of agricultural products.

\section{References}

1. Backović, M., Vuleta, J., Popović, Z. (2014). Ekonomsko-matematički metodi $i$ modeli. CID Ekonomski fakultet Beograd.

2. Basten, R.J.I., Houtum, G.J. (2014). System-oriented inventory models for spare parts. Surveys in Operations Research and Management Science, vol. 19, No.1, pp. 85-96.

3. Božić, V., Aćimović, S. (2010). Marketing logistika. CID Ekonomski fakultet Beograd.

4. Brown, A.S. (2008). To what extent does agricultural machinery maintenance pose clinical risk? Clinical Risk March, vol. 14, No. 2, pp. 59-62.

5. Caffaro, F., Mirisola, A., Cavallo, E. (2017). Safety signs on agricultural machinery: Pictorials do not always successfully convey their messages to target users, Applied Ergonomics, vol. 58, No 1, pp. 156-166.

6. Cruz, A.M., Rincon, A.M.R. (2012). Agricultural machinery maintenance outsourcing: Have operation management research and management theories forgotten the medical engineering community? A mapping review. European Journal of Operational Research, vol. 221, No.1, pp. 186-197.

7. Deshpande, V., Iyer, A.V., Cho, R. (2006). Efficient supply chain management at the U.S. Coast Guard using part-age dependent supply replenishment policies. Oper. Res. vol. 54, No.6, pp. 1028-1040.

8. Gauchan, D., Shrestha, S. (2017). Agricultural and rural mechanization in Nepal: 
status, issues and options for future. In: Mandal, M.A.S. (et al. (eds.)) Rural mechanization: a driver in agricultural change and rural development. Dhaka (Bangladesh): Institute for Inclusive Finance and Development (InM) pp. 97-118.

9. Gościański, M., Kośmicki, Z., Mielec, K. (2005). Chemically polluted parts of agricultural machines which were executed from plastic. Journal of Research and Applications in Agricultural Engineering, vol. 50, No. 4, pp. 32-38.

10. Guillermo, R.G. (2017). Characterization of traditional production systems of sugarcane for panela and some prospects for improving their sustainability, Rev. Fac.Nal.Agr.Medellín, vol.70 no. 1, pp. 8046-8055.

11. Harrington, L. (2007). From just in case to just in time. Air Transp. World, vol. 44, No.4, pp. $77-80$.

12. Karugia, J. (2017). Impact of Farm Mechanization on Crop Production and Yields: Case of interventions implemented under ASDP, 3rd Annual Agriculture Policy Conference 1st - 3rd March, 2017, Dar es Salaam, Tanzania, pp. 170-182.

13. Kranenburg, B. (2006). Spare Parts Inventory Control Under System Availability Constraints (Ph.D. thesis). BETA Research School. Eindhoven, The Netherlands, D88.

14. Milić, B. (2011). Ruralni razvoj - praktikum za lokalne aktere. Stalna konferencija gradova i opština, Beograd.

15. Milojević, I., Mihajlović, M., Cvijanović, M. (2012). Impact of organizational failure of relevance consolidated budget. Ekonomika poljoprivrede, vol. 59, No.1, pp. 63-71.

16. Riveiro, J.A., Marey-Pérez, M.F., Díaz-Varelam, E.R., Álvarez, C.J. (2010). A methodology for the analysis of the relationships between farms and their physical environment. Journal of Agricultural Science vol. 48, No. 2, pp. 245-253.

17. Rustenburg, W.D., Van Houtum, G.J., Zijm, W.H.M. (2013). Exact and approximate analysis of multi-echelon, multi-indenture spare parts systems with commonality, in: Shanthikumar, J.G., Yao, D.D., Zijm, W.H.M. (2013). Stochastic Modelling and Optimization of Manufacturing Systems and Supply Chains: Kluwer Academic Publishers.

18. Smith, A, Pitt, M. (2007). Facilities management quality and user satisfaction in outsourced services. School of the Built Environment. Liverpool John Moores University.

19. Vukoje, A. (2013). Faktori egzistencije kao uslov stvaranja tržišne pozicije preduzeća, ODITOR, Centar za ekonomska i finansijska istraživanja, vol. 1, no. 5, pp. 27-37, Beograd, Srbija.

20. Walczak, M., Caban, J., Marczuk, A. (2017). Evaluation of Tribological Properties of Polymer Materials Used for Sliding Bearings in Agricultural Machinery, Agricultural Engineering, Vol. 21, No. 1, pp. 95-103.

21. Zekić, M, Šegrt, S. (2015). Uticaj privatnog zdravstvenog osiguranja na makroekonomski ambijent Republike Srbije. ODITOR, Centar za ekonomska i finansijska istraživanja, vol. 3, No.1, 33-45, Beograd. 


\title{
ANALIZA OPTIMALNOSTI TROŠKOVA ZALIHA REZERVNIH DELOVA POLjOPRIVREDNIH MAŠINA
}

\author{
Marjan Mirčevski', Milan Mihajlovic ${ }^{10}$, Milan Milunović ${ }^{11}$, Ivan Milojevićc ${ }^{12}$, \\ Radovan Damnjanovićc ${ }^{13}$, Rade Ž ugić ${ }^{14}$, Miloš Miljković ${ }^{15}$, Slobodan Stanojevićc ${ }^{16}$
}

\begin{abstract}
Sažetak
Upravljanje zalihama rezervnih delova poljoprivrednih mašina u poljoprivrednm gazdinstvima predstavlja jednu od najvažnijih aktivnosti u obezbeđivanju nesmetanog funkcionisanja naročito imajući u vidu imperativ kontinuirane proizvodnje. Cilj ove studije bio je da se prikaže kako jednim stohastičkim modelom zaliha može da se utvrdi da pravovremenom nabavkom rezervnih delova može da se obezbedi sa jedne strane ekonomičnost poslovanja poljoprivrednog gazdinstva kao poslovnog subjekta, a sa druge strane smanji vreme neispravnosti poljoprivrednih mašina. Studija optimalnosti nivoa zaliha sprovedena je u poljoprivrednim gazdinstvima na teritoriji Banata u 2015. godini na osnovu podataka o nabavkama rezervnih delova i neispravnostima poljoprivrednih mašina. Prikupljeni podaci su se odnosili na učestalost javljanja neispravnosti i potrebe za rezervnim delovima, kao i cene rezervnih delova, pri čemu su obrađeni primenom stohastičkog modela zaliha. Rezultati: U posmatranom periodu optimalni broj rezernih delova za posmatranu opremu je iznosio $u^{*=4}$ pri čemu se, sa verovatnoćom od 85\%, može tvrditi da će ova količina rezervnih delova biti dovoljna da se otklone svi kvarovi na opremi, dok se preuzima rizik od 15\% da će se jedan ili dva rezervna dela nabaviti hitnim nabavkama u slučaju vanrednih okolnosti. Ovako predstavljen model upravljanja zalihama pruža mogućnost da se lako primeni u poljoprivrednm gazdinstvima, gde bi se uz prethodno izabrane vrednosti odgovarajuci ih prametara efektivno dobile vrednosti optimalnog rešenja, tako da se minimizira ukupan očekivani trošak, koji bi obuhvatao fiksne troškove, troškove izazvane sa nezadovoljenim zahtevima i gde bi se uzelo u obzir vreme čekanja popravke posmatrane opreme.
\end{abstract}

Key words: stohastički model zaliha, rezervni delovi, poljoprivredne mašine, poljoprivredno gazdinstvo.

9 dr Marjan Mirčevski, docent, Vojnomedicinska akademija, Beograd, Crnotravska 17, 11000 Beograd, Srbija, E-mail: marjan.mircevski@gmail.com

10 dr Milan Mihajlović, docent, Vojna akademija, Univerzitet odbrane, Pavla Jurišića Šturma br. 33, 11000 Beograd, Srbija, e-mail:milan.mih83@gmail.com.

11 dr Milan Milunović, docent, Uprava za budžet, Ministarstvo odbrane, Birčaninova 5, 11000 Beograd, Srbija.

12 dr Ivan Milojević, Generalštab Vojske Srbije, Beograd, Gardijska 7, 11000 Beograd, Srbija.

13 dr Radovan Damnjanović, docent, Generalštab Vojske Srbije, Beograd, Gardijska 7, 11000 Beograd, Srbija, E-mail: radovandam78@gmail.com

14 dr Rade Žugić, Vanredni profesor, Visoka škola za menadžment i ekonomiju, Karađorđeva 52, 34000 Kragijevac, Srbija.

15 Miloš Miljković, student master studija, Vojna akademija, Univerzitet odbrane, Pavla Jurišića Šturma br. 33, 11000 Beograd, Srbija

16 dr Slobodan Stanojević, docent, Visoka škola modernog biznisa, Beograd, Terazije 27. 